\title{
INTERAKSI MOLEKULER INHIBITOR DIPEPTIDYL PEPTIDASE-IV (DPP-IV) DARI PROTEIN SUSU KAMBING SECARA IN SILICO SEBAGAI KANDIDAT ANTIDIABETES
}

\author{
MOLECULAR INTERACTIONS OF DIPEPTIDYL PEPTIDASE-IV \\ (DPP-IV) INHIBITORS FROM PROTEIN OF GOAT MILK THROUGH \\ IN SILICO AS ANTIDIABETES CANDIDATE
}

\author{
Taufik Muhammad Fakih*, Mentari Luthfika Dewi \\ Program Studi Farmasi, Fakultas Matematika dan Ilmu Pengetahuan Alam, \\ Universitas Islam Bandung \\ *Penulis Korespondensi, e-mail: taufikmuhammadf@gmail.com
}

\begin{abstract}
ABSTRAK
Dipeptidyl peptidase-IV (DPP-IV) merupakan salah satu target dalam pengobatan diabetes tipe-2. Beberapa obat golongan gliptin yang tersedia secara komersial seperti sitagliptin, anagliptin, linagliptin, saxagliptin, dan alogliptin secara khusus digunakan sebagai inhibitor DPP-IV untuk pasien diabetes. Saat ini, penggunaan peptida pada protein susu kambing untuk mengobati diabetes telah dilaporkan dalam berbagai percobaan in vitro. Namun, pemahaman tentang interaksi molekuler penghambatan peptida tersebut terhadap DPP-IV masih kurang. Penelitian ini bertujuan untuk melakukan identifikasi, evaluasi, dan eksplorasi mengenai afinitas beberapa molekul peptida tersebut, yaitu MHQPPQPL, SPTVMFPPQSVL, VMFPPQSVL, INNQFLPYPY, dan AWPQYL terhadap makromolekul DPP-IV dengan menggunakan simulasi penambatan molekuler berbasis protein-peptida. Sekuensing peptida terlebih dahulu dilakukan pemodelan dengan menggunakan server PEP-FOLD. Konformasi terbaik dipilih untuk dilakukan studi interaksi terhadap makromolekul DPP-IV dengan menggunakan software HPEPDock. Identifikasi lebih lanjut dilakukan terhadap interaksi molekuler yang terbentuk dengan menggunakan software BIOVIA Discovery Studio 2020. Berdasarkan hasil dari penambatan molekuler berbasis protein-peptida diperoleh bahwa molekul peptida INNQFLPYPY memiliki afinitas yang paling baik terhadap makromolekul DPP-IV, yaitu dengan nilai energi bebas ikatan $-923,46 \mathrm{~kJ} / \mathrm{mol}$. Dengan demikian, peptida tersebut diprediksi dapat digunakan sebagai kandidat inhibitor DPP-IV.
\end{abstract}

Kata kunci: Dipeptidyl peptidase-IV (DPP-IV), peptida, protein susu kambing, penambatan molekuler berbasis protein-peptida, studi in silico 


\section{ABSTRACT}

Dipeptidyl peptidase-IV (DPP-IV) is one of the targets in the treatment of type-2 diabetes. Some commercially available gliptin drugs such as sitagliptin, anagliptin, linagliptin, saxagliptin, and alogliptin are specifically used as DPP-IV inhibitors for diabetic patients. Currently, the use of peptides in goat milk protein to treat diabetes has been reported in various in vitro trials. However, understanding of the molecular interactions of peptide inhibition against DPP-IV is still lacking. This study aims to identify, evaluate, and explore the affinity of some of these peptide molecules, namely $M H Q P P Q P L, S P T V M F P P Q S V L, V M F P P Q S V L, I N N Q F L P Y P Y$, and AWPQYL against $D P P-I V$ macromolecules using protein-peptide docking simulations. Peptide sequencing is first carried out modeling using PEP-FOLD software. The best conformation was chosen for the interaction study against DPP-IV macromolecules using HPEPDock software. Further identification was carried out on molecular interactions formed using BIOVIA Discovery Studio 2020 software. Based on the results of protein-peptide docking, it was found that the INNQFLPYPY peptide molecule had the best affinity against DPP-IV macromolecules, with a binding free energy value of $-923,46 \mathrm{~kJ} / \mathrm{mol}$. Therefore, the peptide is predicted to be used as a DPP-IV inhibitor candidate.

Keywords: Dipeptidyl peptidase-IV (DPP-IV), peptide, goat milk protein, protein peptide docking, in silico study

\section{PENDAHULUAN}

Diabetes tipe-2 adalah gangguan metabolisme kronis yang dapat mempengaruhi kualitas hidup. Saat ini, diabetes menduduki peringkat ke delapan sebagai penyebab utama kematian dengan 1,5 juta kematian dan 90\% diantaranya berasal dari diabetes tipe-2 (Drucker and Nauck, 2006). Penyebab utama diabetes tipe-2 adalah glukosa darah yang berlebihan dan ketidakmampuan tubuh untuk memproduksi insulin yang cukup atau dikenal dengan istilah resistensi insulin. Resistensi tubuh terhadap insulin menyebabkan glukosa tetap berada dalam darah sehingga dapat merusak organ lain karena kadar gula yang tinggi. Keadaan tersebut berakibat pada hilangnya kemampuan penglihatan, gagal ginjal, dan penyakit kardiovaskular.

Salah satu cara mengendalikan kadar glukosa darah adalah melalui penghambatan dipeptidyl peptidase-IV (DPP-IV), sebuah serine peptidase yang bertanggung jawab dalam mengubah inkretin menjadi metabolit yang tidak aktif. Inkretin atau glucagonlike peptide-1 (GLP-1) memiliki peran penting dalam merangsang sekresi insulin yang bergantung pada glukosa. Oleh karena itu, penghambatan dipeptidyl peptidase-IV mampu meningkatkan tingkat sirkulasi GLP-1, kemudian merangsang biosintesis dan 
sekresi insulin serta dapat mengembalikan kondisi hiperglikemik pada diabetes tipe-2 (Lovshin and Drucker, 2009).

Terapi dengan antidiabetes golongan gliptin telah mengubah pola penggunaan antidiabetes (Gupta and Kalra, 2011). Obat golongan ini mampu meningkatkan konsentrasi hormon inkretin, meningkatkan kadar insulin, dan menurunkan kadar glukagon dalam sirkulasi darah. Sebagian besar pasien diabetes memilih obat ini karena memiliki efektifitas yang sama dengan obat golongan sulfonilurea seperti metformin. Sampai sekarang terdapat delapan senyawa antidiabetes gliptin yang telah dikembangkan secara sintetis, seperti sitagliptin, anagliptin, linagliptin, saxagliptin, alogliptin, vildagliptin, teneligliptin, gemigliptin, dan dutogliptin (Bolen and Maruthur, 2016; Doggrell and Dimmitt, 2016). Namun, penggunaan obat ini telah banyak menyebabkan efek samping fatal yang berhubungan dengan risiko tinggi penyakit kardiovaskular, peradangan pankreas, reaksi alergi, dan rheumatoid arthritis ( $\mathrm{Li}$ et al., 2016; Tseng, 2016).

Sejalan dengan penemuan dan pengembangan inhibitor DPP-IV, terdapat sumber potensial dari peptida pada protein susu kambing yang memiliki aktivitas antidiabetes. Sebagaimana yang dinyatakan dalam Chinese Compendium of Materia Medica, apabila dibandingkan dengan susu sapi, susu kambing memiliki keunikan tersendiri karena memiliki berbagai fungsi dan dianggap bermanfaat untuk pengobatan (Lacroix and Li-Chan, 2012; Uenishi et al., 2012). Penelitian sebelumnya telah membuktikan bahwa kandungan protein susu kambing memiliki potensi yang lebih tinggi daripada protein pada susu sapi. Beberapa peptida dari protein susu kambing yang memiliki kemampuan dalam menghambat DPP-IV telah berhasil diisolasi dan diidentifikasi berdasarkan serangkaian teknik pemisahan dan identifikasi (Lafarga et al., 2016; Nongonierma and FitzGerald, 2013). Sekuensing dari peptida tersebut antara lain adalah lima oligopeptida yang relatif besar (MHQPPQPL, SPTVMFPPQSVL, VMFPPQSVL, INNQFLPYPY, dan AWPQYL) (Zhang et al., 2015).

Dalam penelitian ini akan dilakukan identifikasi, evaluasi, dan eksplorasi terhadap aktivitas beberapa peptida dari protein susu kambing yang memiliki potensi sebagai inhibitor DPP-IV. Studi komputasi dengan memanfaatkan metode penambatan molekuler berbasis protein-peptida dipilih untuk menjelaskan lebih lanjut mengenai 
afinitas dan interaksi paling baik dari peptida tersebut sehingga diperoleh struktur molekul peptida acuan sebagai kandidat antidiabetes.

\section{METODE PENELITIAN}

\section{Alat dan Bahan}

Bahan yang digunakan dalam penelitian ini adalah struktur kristal makromolekul dipeptidyl peptidase-IV (DPP-IV) yang membentuk kompleks dengan sitagliptin (Gambar 1). Makromolekul tersebut diperoleh dari web Protein Data Bank (http://www.rcsb.org/pdb) dengan kode PDB 1X70 dan memiliki resolusi 2,10 (Gambar 1) (D. Kim et al., 2005). Molekul peptida yang digunakan dalam penelitian ini merupakan peptida yang berasal dari protein susu kambing dan telah dibuktikan memiliki aktivitas terhadap DPP-IV pada penelitian sebelumnya. Sekuensing dari peptida tersebut yaitu MHQPPQPL, SPTVMFPPQSVL, VMFPPQSVL, INNQFLPYPY, dan AWPQYL (Zhang et al., 2015). Software yang digunakan dalam penelitian ini diantaranya terdapat Sistem Operasi Windows 10 dan Linux Ubuntu 18.10, MGLTools 1.5.6 yang dilengkapi dengan AutoDock 4.2, PEP-FOLD (http://bioserv.rpbs.univ-paris-diderot.fr/PEP-FOLD/), HPEPDock, serta BIOVIA Discovery Studio 2020. Hardware yang digunakan dalam penelitian ini adalah komputer dengan spesifikasi processor Intel (R) Core i3-6100 CPU @ 2.30GHz (4 CPUs), memory 4096 MB RAM, Harddisk 320GB, dan VGA Intel HD Graphics 520.

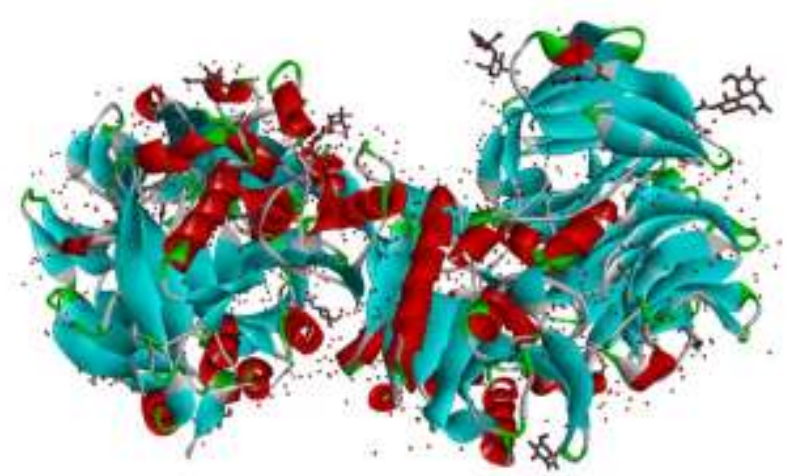

Gambar 1. Struktur kristal makromolekul dipeptidyl peptidase-IV (DPP-IV) yang membentuk kompleks dengan sitagliptin 
Jalannya Penelitian

Preparasi Makromolekul Dipeptidyl Peptidase-IV (DPP-IV)

Struktur kristal makromolekul dipeptidyl peptidase-IV (DPP-IV) yang telah diunduh dari web Protein Data Bank kemudian dilakukan preparasi terlebih dahulu dengan menggunakan software MGLTools 1.5.6 yang dilengkapi dengan AutoDock 4.2. Preparasi makromolekul ini dilakukan dengan menghilangkan molekul air dan sitagliptin yang berperan sebagai ligan alami, selanjutnya dengan menambahkan atom hidrogen polar dan menghitung muatan parsial Kollman (Kurniawan et al., 2018).

Identifikasi sisi aktif Makromolekul Dipeptidyl Peptidase-IV (DPP-IV)

Makromolekul dipeptidyl peptidase-IV (DPP-IV) yang telah dilakukan preparasi kemudian diidentifikasi dan dievaluasi bagian sisi aktif pengikatan yang bertanggung jawab terhadap aktivitas antidiabetes dengan menggunakan software BIOVIA Discovery Studio 2020 (Kemmish et al., 2017). Molekul sitagliptin yang berperan sebagai ligan alami dari makromolekul DPP-IV digunakan untuk mengidentifikasi dan mengevaluasi area sisi aktif dari makromolekul tersebut.

Pemodelan molekul peptida protein susu kambing

Pemodelan molekul peptida yang berasal dari protein susu kambing dilakukan dengan menggunakan server PEP-FOLD (http://bioserv.rpbs.univ-paris-diderot.fr/PEPFOLD/) (Gambar 2). Server PEP-FOLD merupakan suatu software yang digunakan untuk melakukan pemodelan sekuensing peptida menjadi konformasi 3D secara de novo dengan jumlah asam amino antara 9 sampai 25 (Chavan and Deobagkar, 2015).
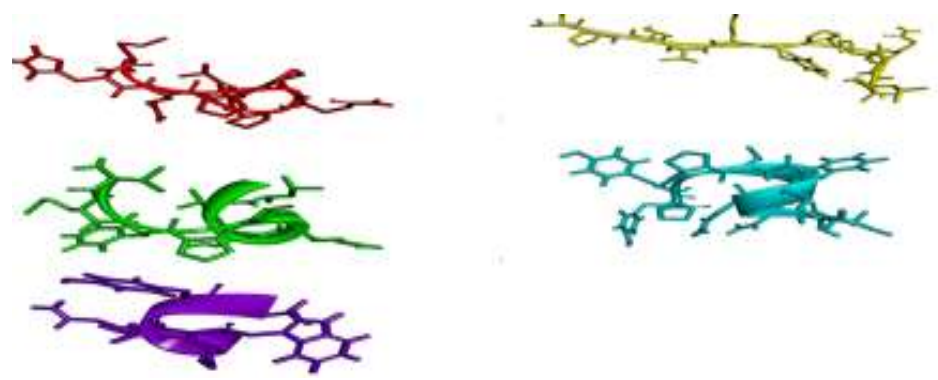

Gambar 2. Struktur molekul peptida MHQPPQPL (merah), SPTVMFPPQSVL (kuning), VMFPPQSVL (hijau), INNQFLPYPY (biru), dan AWPQYL (ungu) 
Simulasi penambatan molekuler berbasis protein-peptida

Simulasi penambatan molekuler berbasis protein-peptida dilakukan dengan menggunakan software HPEPDock untuk mengidentifikasi dan mengevaluasi interaksi yang terjadi antara makromolekul dipeptidyl peptidase-IV (DPP-IV) dengan molekul peptida protein susu kambing. Jarak antara permukaan makromolekul DPP-IV dan molekul peptida dibatasi dengan batas radius maksimum 4.0 A. Simulasi penambatan molekuler ini menggunakan parameter dengan berdasarkan pada representasi bentuk molekul, bagian sisi aktif pengikatan makromolekul, serta pemilihan dan penilaian. Simulasi penambatan molekuler ini juga dilakukan secara efisien tanpa adanya ikatan yang rigid antar molekul (Zhou et al., 2018).

Analisis Hasil Simulasi Penambatan Molekuler Berbasis Protein-Peptida

Dilakukan identifikasi dan evaluasi terhadap hasil simulasi penambatan molekuler berbasis protein-peptida dengan mengamati interaksi yang terjadi antara makromolekul dipeptidyl peptidase-IV (DPP-IV) dengan molekul peptida protein susu kambing berdasarkan nilai energi bebas ikatan (Zhou et al., 2018). Residu asam amino yang bertanggung jawab dalam interaksi molekuler yang terbentuk dieksplorasi dengan menggunakan software BIOVIA Discovery Studio 2020.

\section{HASIL DAN PEMBAHASAN}

Dipeptidyl peptidase-IV (DPP-IV) merupakan target baru dalam pengobatan diabetes mellitus tipe 2 karena mampu menurunkan inkretin seperti glucagon-like peptide-1 (GLP-1) dan glucose-dependent insulinotropic polypeptid. Inhibitor DPP-IV dapat mempersingkat inaktivasi GLP-1 dan memungkinkan inkretin untuk merangsang pelepasan insulin, dengan demikian menurunkan resiko hiperglikemia. Dalam upaya pencarian agen antidiabetes, maka dilakukan pengembangan inhibitor DPP-IV alami berbasis peptida (Kim et al., 2018). Penelitian sebelumnya telah berhasil mengisolasi dan mengidentifikasi beberapa peptida yang berasal dari protein susu kambing. Adapun sekuensing dari peptida tersebut yaitu lima oligopeptida yang relatif besar (MHQPPQPL, SPTVMFPPQSVL, VMFPPQSVL, INNQFLPYPY, dan AWPQYL) (Zhang et al., 2015). Untuk memastikan afinitas dan interaksi dari kelima peptida 
tersebut sebagai inhibitor DPP-IV maka akan dilakukan simulasi penambatan molekuler berbasis protein-peptida secara in silico.

Struktur makromolekul Dipeptidyl peptidase-IV (DPP-IV) dipilih sebagai target untuk mengamati aktivitas dari kelima molekul peptida protein susu kambing. Makromolekul tersebut terlebih dahulu dilakukan preparasi dengan menghilangkan molekul air dan sitagliptin sebagai ligan alami, kemudian tahapan selanjutnya menambahkan atom hidrogen polar, dan menghitung muatan parsial Kollman dengan menggunakan software MGLTools 1.5.6 yang dilengkapi dengan AutoDock 4.2 (Kurniawan et al., 2018). Tahapan preparasi makromolekul ini bertujuan untuk memastikan agar molekul peptida dapat membentuk interaksi yang stabil dengan makromolekul DPP-IV. Di samping itu, sitagliptin yang membentuk kompleks dengan DPP-IV digunakan sebagai molekul pembanding untuk mengamati afinitas dan interaksi yang paling baik.

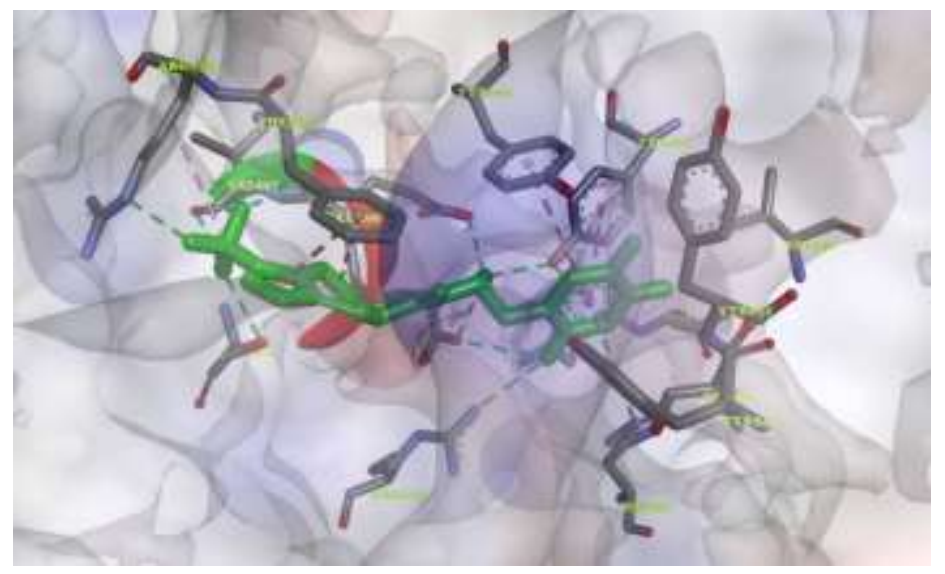

Gambar 3. Bagian sisi aktif pengikatan makromolekul dipeptidyl peptidase-IV (DPP-IV)

Makromolekul dipeptidyl peptidase-IV (DPP-IV) yang telah dilakukan preparasi kemudian diidentifikasi dan dievaluasi bagian sisi aktifnya dengan menggunakan software BIOVIA Discovery Studio 2020 sehingga karakteristik sifat dari area pengikatan pada makromolekul DPP-IV dapat diketahui. Sebagaimana yang ditunjukkan pada Gambar 3, interaksi molekuler yang terbentuk antara makromolekul DPP-IV dengan sitagliptin terdiri dari 9 ikatan hidrogen (dengan Arg125, Glu205, Glu206, Ser209, Arg358, Tyr662, dan Asn710), 6 interaksi hidrofobik (dengan Phe357, Arg358, Tyr662, Tyr666, dan His740), dan 9 ikatan halogen (dengan Arg125, Glu205, 
Glu206, Val207, Ser209, Arg358, dan Asn710). Berdasarkan hasil pengamatan tersebut maka dapat diprediksi bahwa residu asam amino tersebut bertanggung jawab sebagai komponen penyusun dari bagian sisi aktif pengikatan makromolekul DPP-IV (Kim et al., 2005).

Tabel I. Energi sOPEP (Optimized Potential for Efficient Structure Prediction) hasil pemodelan molekul peptida protein susu kambing

\begin{tabular}{cc}
\hline Sekuensing Molekul Peptida & Energi sOPEP \\
\hline MHQPPQPL & $-12,30$ \\
SPTVMFPPQSVL & $-32,10$ \\
VMFPPQSVL & $-32,01$ \\
INNQFLPYPY & $-32,06$ \\
AWPQYL & $-20,17$ \\
\hline
\end{tabular}

Sekuensing peptida protein susu kambing kemudian dimodelkan menjadi struktur tiga dimensi dengan menggunakan server PEP-FOLD. Konformasi yang terbentuk dari hasil pemodelan molekul peptida terbaik dipilih berdasarkan energi sOPEP (Optimized Potential for Efficient Structure Prediction) (Shen at al., 2014; Thévenet et al., 2012). Energi sOPEP yang terintegrasi dalam server PEP-FOLD digunakan untuk menggambarkan konformasi struktur molekul peptida yang dimodelkan sehingga mendekati keadaan aslinya dan diharapkan mampu berinteraksi secara stabil dengan makromolekul dipeptidyl peptidase-IV (DPP-IV). Dari hasil pemodelan molekul peptida yang terdapat pada Tabel I dapat diprediksi bahwa molekul peptida tersebut akan mampu berinteraksi dengan baik pada bagian sisi aktif pengikatan makromolekul DPPIV.

Tabel II. Energi bebas pengikatan hasil studi penambatan molekuler berbasis proteinpeptida

\begin{tabular}{cc}
\hline Sekuensing Molekul Peptida & Energi Bebas Ikatan $(\mathbf{k J} / \mathbf{m o l})$ \\
\hline MHQPPQPL & $-696,75$ \\
SPTVMFPPQSVL & $-834,49$ \\
VMFPPQSVL & $-746,14$ \\
INNQFLPYPY & $-923,46$ \\
AWPQYL & $-776,10$
\end{tabular}


Simulasi penambatan molekuler berbasis protein-peptida dilakukan dengan menggunakan software HPEPDock untuk mengamati afinitas paling baik diantara kelima molekul peptida, serta melakukan identifikasi dan evaluasi interaksi molekuler yang terjadi terhadap makromolekul dipeptidyl peptidase-IV (DPP-IV). Model pengikatan protein-peptida dengan konformasi terbaik hasil penambatan molekuler dibandingkan berdasarkan nilai energi bebas ikatan (Zhou et al., 2018). Berdasarkan data hasil penambatan molekuler yang terdapat pada Tabel II menunjukkan bahwa molekul peptida INNQFLPYPY memiliki afinitas yang paling baik apabila dibandingkan dengan molekul peptida lain, yaitu dengan nilai energi bebas ikatan $-923,46 \mathrm{~kJ} / \mathrm{mol}$. Fenomena tersebut dapat diprediksi bahwa lokasi tempat pengikatan peptida bioaktif INNQFLPYPY berada pada bagian sisi aktif makromolekul DPP-IV dan memiliki kemiripan dengan sitagliptin (Zhou, et al., 2018).

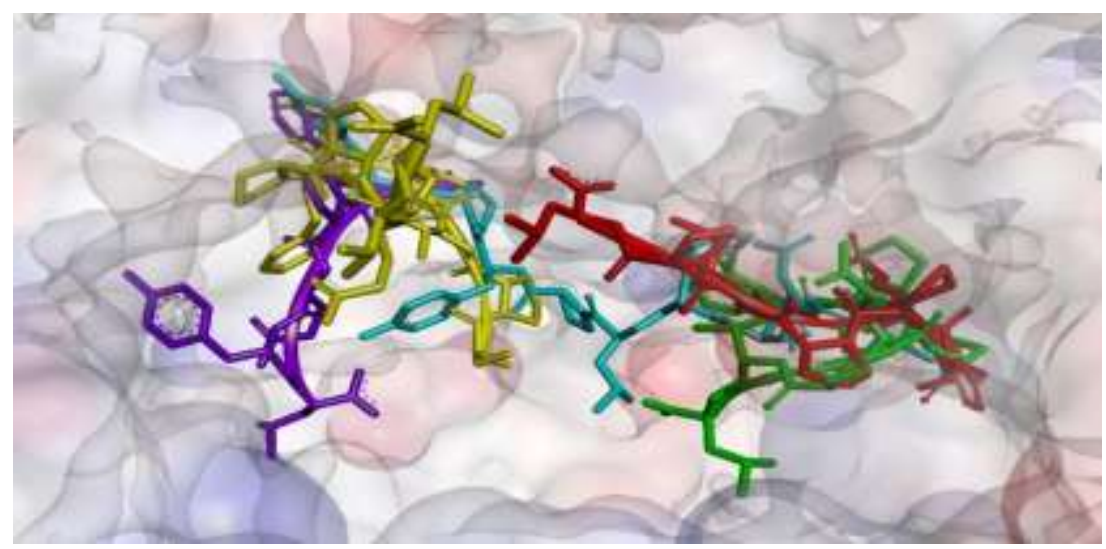

Gambar 4. Konformasi molekul peptida pada bagian sisi aktif pengikatan makromolekul dipeptidyl peptidase-IV (DPP-IV)

Kemudian, dilakukan identifikasi, evaluasi, dan eksplorasi lebih lanjut terhadap visualisasi dari kompleks molekul peptida dan makromolekul dipeptidyl peptidase-IV (DPP-IV). Seperti yang ditunjukkan pada Gambar 4, secara umum kelima molekul peptida memiliki konformasi yang sama dengan sitagliptin pada bagian sisi aktif makromolekul dipeptidyl peptidase-IV (DPP-IV), yaitu mampu berinteraksi dengan residu asam amino Arg125, Glu205, Glu206, Val207, Ser209, Phe357, Arg358, Tyr662, Tyr666, Asn710, dan His740. Akan tetapi, menariknya molekul peptida INNQFLPYPY memiliki jumlah interaksi yang lebih banyak pada bagian sisi aktif DPP-IV yang terdiri 
dari 8 ikatan hidrogen (dengan Ser209, Ser212, Trp215, Asp302, Tyr547, dan Tyr662) dan 4 interaksi hidrofobik (dengan Ala210, Phe357, dan Tyr662). Dengan demikian, fenomena ini membuktikan bahwa afinitas paling baik yang dihasilkan dari molekul peptida INNQFLPYPY dapat disebabkan karena molekul peptida tersebut mampu berinteraksi dengan stabil pada area sisi aktif makromolekul DPP-IV (Norel et al., 2008).

\section{KESIMPULAN}

Molekul peptida INNQFLPYPY telah terbukti mampu menghambat makromolekul dipeptidyl peptidase-IV (DPP-IV) melalui identifikasi, evaluasi, dan eksplorasi terhadap interaksi molekuler yang terjadi dengan menggunakan metode penambatan molekuler berbasis protein-peptida secara in silico. Berdasarkan hasil penambatan molekuler diperoleh bahwa molekul peptida tersebut memiliki afinitas paling baik terhadap bagian sisi aktif pengikatan makromolekul DPP-IV yaitu dengan nilai energi bebas ikatan $-923,46 \mathrm{~kJ} / \mathrm{mol}$. Oleh karena itu, molekul peptida tersebut memiliki potensi sebagai kandidat inhibitor makromolekul DPP-IV untuk pengembangan antidiabetes alami berbasis peptida.

\section{DAFTAR PUSTAKA}

Bolen, S. D., \& Maruthur, N. M. (2016). The safety of incretin based drug treatments for type 2 diabetes. BMJ. 352: 801.

Chavan, S. G., \& Deobagkar, D. D. (2015). An in silico insight into novel therapeutic interaction of LTNF peptide-LT10 and design of structure based peptidomimetics for putative anti-diabetic activity. PLoS ONE, March 2015:1-20

Doggrell, S. A., \& Dimmitt, S. B. (2016). Sitagliptin and other gliptins - Why prescribe them? Expert Opinion on Pharmacotherapy, 17(6): 757-760

Drucker, D. J., \& Nauck, M. A. (2006). The incretin system: glucagon-like peptide-1 receptor agonists and dipeptidyl peptidase- 4 inhibitors in type 2 diabetes. Lancet. 368(9548): 1696-1705.

Gupta, V., \& Kalra, S. (2011). Choosing a Gliptin. Indian Journal of Endocrinology and Metabolism. 15(4): 298-308.

Kemmish, H., Fasnacht, M., \& Yan, L. (2017). Fully automated antibody structure 
prediction using BIOVIA tools: Validation study. PLoS ONE. 12: e0177923.

Kim, B. R., Kim, H. Y., Choi, I., Kim, J. B., Jin, C. H., \& Han, A. R. (2018). DPP-IV inhibitory potentials of flavonol glycosides isolated from the seeds of lens culinaris: In vitro and molecular docking analyses. Molecules. 23: 8.

Kim, D., Wang, L., Beconi, M., Eiermann, G. J., Fisher, M. H., He, H., ... Weber, A. E. (2005). (2R)-4-Oxo-4-[3-(trifluoromethyl)-5,6-dihydro[1,2,4]triazolo[4,3-a] pyrazin-7(8H)-yl]-1-(2,4,5-trifluorophenyl)butan-2-amine: A potent, orally active dipeptidyl peptidase IV inhibitor for the treatment of type 2 diabetes. Journal of Medicinal Chemistry. 48(1): 141-151.

Kurniawan, F., Miura, Y., Kartasasmita, R. E., Mutalib, A., Yoshioka, N., \& Tjahjono, D. H. (2018). In silico study, synthesis, and cytotoxic activities of porphyrin derivatives. 11: 8.. Pharmaceuticals.

Lacroix, I. M. E., \& Li-Chan, E. C. Y. (2012). Evaluation of the potential of dietary proteins as precursors of dipeptidyl peptidase (DPP)-IV inhibitors by an in silico approach. Journal of Functional Foods. 4(2): 403-422.

Lafarga, T., Rai, D. K., O'connor, P., \& Hayes, M. (2016). Generation of Bioactive Hydrolysates and Peptides from Bovine Hemoglobin with In Vitro Renin, Angiotensin-I-Converting Enzyme and Dipeptidyl Peptidase-IV Inhibitory Activities. Journal of Food Biochemistry. 40(5): 673-685.

Li, L., Li, S., Deng, K., Liu, J., Vandvik, P. O., Zhao, P., ... Sun, X. (2016). Dipeptidyl peptidase- 4 inhibitors and risk of heart failure in type 2 diabetes: Systematic review and meta-analysis of randomised and observational studies. The BMJ. 352: 610.

Lovshin, J. A., \& Drucker, D. J. (2009). Incretin-based therapies for type 2 diabetes mellitus. Nature Reviews Endocrinology. 5(5): 262-269.

Nongonierma, A. B., \& FitzGerald, R. J. (2013). Inhibition of dipeptidyl peptidase IV (DPP-IV) by proline containing casein-derived peptides. Journal of Functional Foods. 5(4): 1909-1917.

Norel, R., Sheinerman, F., Petrey, D., \& Honig, B. (2008). Electrostatic contributions to protein-protein interactions: Fast energetic filters for docking and their physical basis. Protein Science. 10: 2147-2161.

Shen, Y., Maupetit, J., Derreumaux, P., \& Tufféry, P. (2014). Improved PEP-FOLD approach for peptide and miniprotein structure prediction. Journal of Chemical Theory and Computation. 10(10): 4745-4758. 
Thévenet, P., Shen, Y., Maupetit, J., Guyon, F., Derreumaux, P., \& Tufféry, P. (2012). PEP-FOLD: An updated de novo structure prediction server for both linear and disulfide bonded cyclic peptides. Nucleic Acids Research. 40: 288-293h.

Tseng, C. H. (2016). Sitagliptin and pancreatic cancer risk in patients with type 2 diabetes. European Journal of Clinical Investigation. 46(1): 70-79.

Uenishi, H., Kabuki, T., Seto, Y., Serizawa, A., \& Nakajima, H. (2012). Isolation and identification of casein-derived dipeptidyl-peptidase 4 (DPP-4)-inhibitory peptide LPQNIPPL from gouda-type cheese and its effect on plasma glucose in rats. International Dairy Journal. 22(1): 24-30.

Zhang, Y., Chen, R., Ma, H., \& Chen, S. (2015). Isolation and Identification of Dipeptidyl Peptidase IV-Inhibitory Peptides from Trypsin/Chymotrypsin-Treated Goat Milk Casein Hydrolysates by 2D-TLC and LC-MS/MS. Journal of Agricultural and Food Chemistry. 63(40): 8819-8828.

Zhou, P., Jin, B., Li, H., \& Huang, S. Y. (2018). HPEPDOCK: A web server for blind peptide-protein docking based on a hierarchical algorithm. Nucleic Acids Research. 46(1): 443-452.

Zhou, P., Li, B., Yan, Y., Jin, B., Wang, L., \& Huang, S. Y. (2018). Hierarchical Flexible Peptide Docking by Conformer Generation and Ensemble Docking of Peptides. Journal of Chemical Information and Modeling. 58(6): 1292-1302. 